This is an author produced version of a paper published in Cellular signalling. This paper has been peer-reviewed but does not include the final publisher proofcorrections or journal pagination.

Citation for the published paper:

Zmuda-Trzebiatowska, Emilia and Oknianska, Alina and

Manganiello, Vincent and Degerman, Eva

"Role of PDE3B in insulin-induced glucose uptake, GLUT-4

translocation and lipogenesis in primary rat adipocytes."

Cell Signal. 2006 Mar;18(3):382-90

http://dx.doi.org/10.1016/j.cellsig.2005.05.007

Access to the published version may require journal subscription.

Published with permission from: Elsevier 


\section{Role of PDE3B in insulin-induced glucose uptake, GLUT-4 translocation and lipogenesis in primary rat adipocytes}

Emilia Zmuda-Trzebiatowska*, Alina Oknianska*, Vincent Manganiello**, Eva Degerman*

*Biomedical Center, C11, Department of Experimental Medical Science, 22184 Lund, Sweden **Pulmonary Critical Care Medicine Branch, NHLB, NIH, Bethesda, Maryland, 20892, USA

Corresponding author:

Emilia Zmuda-Trzebiatowska

Biomedical Center, C11

Department of Experimental Medical Science

22184 Lund, Sweden

Tel: +46462229552

Fax: +46 462224022

e-mail: emilia.zmuda-trzebiatowska@medkem.lu.se 


\section{Abstract}

In adipocytes, phosphorylation and activation of PDE3B is a key event in the antilipolytic action of insulin. The role of PDE4, another PDE present in adipocytes, is not yet known. In this work we investigate the role of PDE3B and PDE4 in insulin-induced glucose uptake, GLUT-4 translocation and lipogenesis. Inhibition of PDE3 (OPC3911, milrinone) but not PDE4 (RO 20-1724) lowered insulin-induced glucose uptake and lipogenesis, especially in the presence of isoproterenol (a general $\beta$-adrenergic agonist), CL316243, a selective $\beta 3$ adrenergic agonist, and pituitary adenylate cyclase-activating peptide. The inhibitory effect of OPC3911 was associated with reduced translocation of GLUT-4 from the cytosol to the plasma membrane. Both OPC3911 and RO 20-1724 increased protein kinase A (PKA) activity and lipolysis. H89, a PKA inhibitor, did not affect OPC3911-mediated inhibition of insulin-induced glucose uptake and lipogenesis, whereas 8-pCPT-2'-O-Me-cAMP, an Epac agonist which mediates PKA independent cAMP signaling events, mimicked all the effects of OPC3911. Insulin-mediated activation of protein kinase B, a kinase involved in insulininduced glucose uptake, was apparently not altered by OPC3911. In summary, our data suggest that PDE3B, but not PDE4, contributes to the regulation of insulin-induced glucose uptake, GLUT-4 translocation, and lipogenesis presumably by regulation of a cAMP/ Epac signalling mechanisms.

Keywords:

PDE3B, PDE4, Epac, GLUT-4, glucose uptake, lipogenesis, adipocyte 


\section{Introduction}

Cyclic nucleotide phosphodiesterases (PDEs) ${ }^{1}$ are important regulators of signal transduction processes mediated by cAMP and cGMP. Eleven PDE families (PDE1-11) have been identified with regard to their substrate affinities, biochemical and physical properties, mechanisms whereby they are regulated, and different sensitivities to inhibitors $[1,2]$. In adipocytes, PDE3B (the PDE3 family consists of two members, PDE3A and PDE3B) plays a key role in the antilipolytic action of insulin [3]. Insulin-induced phosphorylation and activation of PDE3B leads to increased hydrolysis of cAMP, lowering of protein kinase A (PKA) activity and thereby a decrease in PKA-dependent phosphorylation and activation of hormone sensitive lipase and lipolysis [4].

In adipocytes, modulators of cAMP regulate insulin-induced glucose uptake, a process known to involve translocation of insulin sensitive glucose transporters (GLUT-4) from an intracellular pool to the plasma membrane [5]. However, different effects of these agents have been reported. Thus, cAMP-increasing $\beta$-adrenergic agonists have been shown to increase $[6$, 7], to have no effect on [8,9], or to decrease [10-12] insulin-induced glucose uptake in adipocytes. Studies using PDE3 inhibitors, OPC3911 and cilostamide, showed impaired, [13, 14] or unaffected [15] insulin-induced glucose uptake in adipocytes. The role of PDE4, which is also expressed in adipocytes, is not known. RO 20-1724, a PDE4 inhibitor, was found to suppress insulin-induced glucose uptake in myocardium [16], and another PDE4 inhibitor, rolipram, decreased glucose uptake in vivo in brain, heart, and skeletal muscle [17].

In this study we evaluated the role of PDE3B and PDE4 in insulin-induced glucose uptake, GLUT-4 translocation, and lipogenesis. We found that inhibition of PDE3B, but not PDE4, resulted in lowering of all these insulin-induced processes. Furthermore, overexpression of PDE3B resulted in increased lipogenesis. On the other hand, inhibition of PDE3B and PDE4, 
respectively, increased PKA activity and lipolysis to similar extent. An Epac agonist was found to mimic, whereas H89, a PKA inhibitor did not interfere with the ability of OPC3911 to inhibit insulin-induced glucose uptake, GLUT-4 translocation and lipogenesis. These results indicate that $\mathrm{PDE} 3 \mathrm{~B}$ is involved in regulation of insulin-induced glucose uptake, GLUT-4 translocation and lipogenesis, presumably by regulating cAMP/ Epac signalling events.

\section{Materials and methods}

\subsection{Preparation of adipocytes}

Adipocytes were isolated from epididymal fat pads of 36-38 day-old male Sprague-Dawley rats (B\&K Universal, Stockholm) and prepared as described previously [18, 19]. Lund University Ethic Committee approved the study (permission number: M170-03).

\subsection{Lipolysis assay}

Glycerol release was measured as described previously [22]. Four hundred microliter aliquots of 5\% (v/v) adipocytes in $\mathrm{KRH}$ were incubated as indicated in "Results" for 30 min at $37^{\circ} \mathrm{C}$ with shaking. Reactions were stopped by putting the tubes on ice for $20 \mathrm{~min}$. One milliliter of hydrazine buffer containing $50 \mathrm{mM}$ glycine ( $\mathrm{pH} 9.8$ ), $0.05 \%$ hydrazine hydrate, $1 \mathrm{mM} \mathrm{MgCl}$, supplemented with $0.75 \mathrm{mg} / \mathrm{ml}$ ATP, $0.375 \mathrm{mg} / \mathrm{ml}$ nicotinamide adenine dinucleotide, 25 $\mu \mathrm{g} / \mathrm{ml}$ glycerol-3-phosphate dehydrogenase, and $0.5 \mu \mathrm{g} / \mathrm{ml}$ glycerokinase was added to $200 \mu \mathrm{l}$ of collected media. After incubation for $40 \mathrm{~min}$ in room temperature, $\mathrm{OD}_{340}$ was measured and glycerol release was calculated. 


\subsection{Glucose uptake assay}

2-deoxy-D-[1- $\left.{ }^{3} \mathrm{H}\right]$-glucose uptake was measured as described [20]. One hundred microliters of 30\% (v/v) adipocytes in Krebs-Ringer bicarbonate-HEPES (KRBH) buffer (120 mM NaCl, $4 \mathrm{mM} \mathrm{KH}_{2} \mathrm{PO}_{4}, 1 \mathrm{mM} \mathrm{MgSO} 4,0.75 \mathrm{mM} \mathrm{CaCl}_{2}, 10 \mathrm{mM} \mathrm{NaHCO} 3,30 \mathrm{mM}$ HEPES, pH 7.4) with $1 \%$ bovine serum albumin (BSA) was added to $100 \mu$ of $\mathrm{KRBH}$ buffer supplemented as indicated in "Results" and incubated for $10 \mathrm{~min}$ at $37^{\circ} \mathrm{C}$. Fifty microliter aliquots of KRBH buffer containing $0.5 \mathrm{mM}$ 2-deoxyglucose, $0.5 \mu \mathrm{Ci}$ 2-deoxy-D-[1- $\left.{ }^{3} \mathrm{H}\right]$-glucose (Amersham) and either $60 \mu \mathrm{M}$ cytochalasin $\mathrm{b}$ in DMSO or DMSO alone were added. After $10 \mathrm{~min}$ reactions were stopped with $10 \mu 1.5 \mathrm{mM}$ cytochalasin b. Cells were separated from the buffer by centrifugation $(6000 \mathrm{xg})$ through dinonyl phtalate for $1 \mathrm{~min}$. 2-deoxy-D-[1- $\left.{ }^{3} \mathrm{H}\right]-$ glucose uptake was determined by scintillation counting.

\subsection{Lipogenesis assay}

Lipogenesis was measured as previously described [21]. One milliliter aliquots of $2 \%(\mathrm{v} / \mathrm{v})$ adipocytes in Krebs-Ringer-HEPES (KRH) buffer with low glucose $(0.55 \mathrm{mM})$ and $3.5 \%$ BSA were added to vials containing $0,4 \mu \mathrm{Ci}$ D-[6- $\left.{ }^{3} \mathrm{H}\right]$-glucose (Amersham) and incubated as indicated in "Results" for $10 \mathrm{~min}$ (fresh adipocytes) or for $30 \mathrm{~min}$ (adipocytes infected with adenovirus carrying cDNA for $\beta$ galactosidase or Flag-PDE3B) at $37{ }^{\circ} \mathrm{C}$. Reactions were stopped with a toluol-based scintillation liquid containing $0.3 \mathrm{~g} / 1$ POPOP (1, 4-bis[5-phenyl2-oxazolyl]benzene, 2,2'-p-phenylene-bis[5-phenyloxazole]) and 5 g/l PPO (2,5-diphenyl oxazole). Incorporation of D-[6- $\left.{ }^{3} \mathrm{H}\right]$-glucose into cellular lipids was measured by scintillation counting. 
One milliliter aliquots of $6 \%(\mathrm{v} / \mathrm{v})$ adipocytes in KRH buffer, $\mathrm{pH} 7.4$ with $1 \%$ BSA were incubated as indicated in "Results" for $1 \mathrm{~min}$ at $37^{\circ} \mathrm{C}$. After addition of $200 \mu \mathrm{l}$ of ice-cold homogenization buffer (5 mM Tris, 5 mM EDTA, 1.5 mM IBMX, $50 \mu$ M OPC 3911, $5 \mu \mathrm{g} / \mathrm{ml}$ pepstatin $\mathrm{A}, 50 \mu \mathrm{g} / \mathrm{ml}$ antipain, $50 \mu \mathrm{g} / \mathrm{ml}$ leupeptin, $\mathrm{pH}$ 7.4) the cells were homogenized and centrifuged $\left(15500 \mathrm{xg}\right.$ for $10 \mathrm{~min}$ at $\left.4^{\circ} \mathrm{C}\right)$. Ten microliters of infranatant was incubated with 5 $\mu \mathrm{l}$ of phosphorylation mix (20 mM TES $\left(\mathrm{C}_{6} \mathrm{H}_{15} \mathrm{NO}_{6} \mathrm{~S}\right), 250 \mathrm{mM}$ sucrose, $50 \mathrm{mM} \mathrm{MgSO} 4,0.2$ $\mathrm{mM}$ ATP, $5 \mathrm{mM}$ dithioerythriol, $4 \mathrm{mg} / \mathrm{ml}$ kemptide, and $5 \mu \mathrm{Ci}\left[\gamma^{32}{ }^{32} \mathrm{P}\right] \mathrm{ATP}$ with or without 10 $\mu \mathrm{M}$ protein kinase A inhibitor) for $30 \mathrm{~min}$ at $30^{\circ} \mathrm{C}$. Reactions were stopped with $10 \mu 1$ of stopmix (1\% BSA, 1 mM ATP, pH 3.0). Proteins were precipitated with $30 \%$ trichloroacetic acid for $15 \mathrm{~min}$ on ice. After centrifugation $(9200 \mathrm{xg})$ at $4^{\circ} \mathrm{C}$ for $3 \mathrm{~min}, 10 \mu \mathrm{l}$ aliquots of each sample were transferred to P- 81 membranes. The membranes were washed three times in 75 $\mathrm{mM} \mathrm{H} \mathrm{H}_{3} \mathrm{PO}_{4}$ and once in acetone. The amount of incorporated ${ }^{32} \mathrm{P}$ was determined by scintillation counting.

\subsection{Subcellular fractionation of adipocytes}

Seven milliliter aliquots of $10 \%(\mathrm{v} / \mathrm{v})$ adipocytes in $\mathrm{KRH}$ were incubated as indicated in "Results" for $10 \mathrm{~min}$ at $37^{\circ} \mathrm{C}$. Cells were then homogenized in $3 \mathrm{ml}$ of homogenization buffer (40 mM HEPES, $10 \mathrm{mM} \mathrm{NaF,} 1 \mathrm{mM}$ dithioerythriol, $1 \mathrm{mM}$ phenylmethylsulphonylfluoride, $0.25 \mathrm{mM}$ sodium orthovanadate, $10 \mu \mathrm{g} / \mathrm{ml}$ antipain, $10 \mu \mathrm{g} / \mathrm{ml}$ leupeptin and $1 \mu \mathrm{g} / \mathrm{ml}$ pepstatin A, $\mathrm{pH} 7.4$ ) and centrifuged at $16600 \mathrm{xg}$ for $15 \mathrm{~min}$ at $4^{\circ} \mathrm{C}$. The solidified fat was removed and the infranatant was used to prepare the microsomal fraction. The $16600 \mathrm{xg}$ pellet was resuspended in $1.5 \mathrm{ml}$ of homogenization buffer, layered on top of a $1.5 \mathrm{ml}$ sucrose cushion 
(1.12M sucrose, $20 \mathrm{mM}$ Tris PH 7.4, $1 \mathrm{mM}$ EDTA) and centrifuged at $104000 \mathrm{xg}$ for $70 \mathrm{~min}$ at $4^{\circ} \mathrm{C}$. Plasma membranes, collected at the sucrose-buffer interface, were centrifuged at $48000 \mathrm{xg}$ for $45 \mathrm{~min}$ at $4^{\circ} \mathrm{C}$ and resuspended in $200 \mu \mathrm{l}$ of homogenization buffer. The initial infranatant was centrifuged at $48000 \mathrm{xg}$ for $20 \mathrm{~min}$ at $4^{\circ} \mathrm{C}$, yielding a high density microsomal (HDM) fraction which was resuspended in $200 \mu$ of homogenization buffer. By centrifugation of the supernatant at $216000 \mathrm{xg}$ for $70 \mathrm{~min}$ at $4^{\circ} \mathrm{C}$ a low density microsomal (LDM) fraction was obtained. The pellet was resuspended in $200 \mu$ of homogenization buffer.

\subsection{SDS-PAGE and western blot analysis}

After protein concentration had been measured (Bradford [23]), the samples were mixed with Laemmli sample buffer and subjected to polyacrylamide gel electrophoresis (PAGE) (10\% acrylamide) and western blot analysis. After the electrotransfer of proteins onto a polyvinylidene difluoride membrane (Millipore) or Hybond-C membrane (Amersham Biosciences), membranes were blocked for 30 min with 5\% milk in TBS-T buffer (50 mM Tris $\mathrm{pH} 7.5,150 \mathrm{mM} \mathrm{NaCl}$ and $0.1 \%$ (w/v) Tween-20), and incubated overnight with a 1:2000 dilution of anti-GLUT4 antibodies (Santa Cruz Biotechnology), a 1:1000 dilution of anti-GEF antibodies (Santa Cruz Biotechnology), anti P-Ser473PKB $\alpha$ antibodies (a kind gift from Professor Lars Rönnstrand) or a 1:1000 dilution of anti-PDE3B antibodies (raised in rabbits as described, see 24). After washing in TBS-T buffer membranes were incubated for 1h with 1:5000 dilution of anti-rabbit antibodies linked with Horseradish peroxidase (Amersham), washed again and developed with the 1:1 solution of Peroxide and Luminol (Pierce). The chemoluminescent signal was analyzed and quantified with use of the Fuji LAS 1000 Plus system (Fuji Photo Film, Tokyo, Japan). 


\subsection{Adenovirus infection and cell treatment}

High titer adenoviral stocks (approximately $10^{10} \mathrm{pfu} / \mathrm{ml}$ ) were used to infect primary rat adipocytes (2-3 $\mathrm{ml}$ of $12 \%$ cells) as indicated in the figure legend. Infection was performed for16 hours in DMEM supplemented with $0.5 \% \mathrm{BSA}$ and $5 \% \mathrm{FCS}$ at $37^{\circ} \mathrm{C}, 5 \% \mathrm{CO}_{2}$. Control virus expressing $\beta$-galactosidase (AdV $\beta$-gal) and adenoviral vectors were kindly provided by Drs. C.N. Newgard and H. Mulder. Flag-PDE3B-expressing virus (AdFlag-PDE3B) was constructed as previously described [25].

\subsection{Determination of PDE3 activity}

Primary adipocytes infected for 16 hours with AdV $\beta$-gal or AdVPDE3B-Flag were washed in KRH buffer and homogenized (10 strokes at room temperature) in homogenization buffer (50 mM N-tris(hydroxymethyl)-methyl-2-aminoethanesulfonic acid (TES), $40 \mathrm{mM}$ p-nitrophenyl-phosphate, $2 \mathrm{mM}$ EGTA, $1 \mathrm{mM}$ EDTA, $250 \mathrm{mM}$ sucrose, $1 \mathrm{mM}$ dithioerytritol, 0.05 $\mathrm{mM}$ vanadate, $10 \mu \mathrm{g} / \mathrm{ml}$ antipain, $10 \mu \mathrm{g} / \mathrm{ml}$ leupeptin, $1 \mu \mathrm{g} / \mathrm{ml}$ pepstatin $\mathrm{A}, \mathrm{pH}$ 7.4). The cell homogenates were centrifuged at $33000 \mathrm{x} \mathrm{g}$ for $45 \mathrm{~min}$ at $4^{\circ} \mathrm{C}$ and the crude membrane fractions were resuspended in homogenization buffer. PDE3 activity was measured as described previously [26]. Assays were performed at $30^{\circ} \mathrm{C}$ for $15 \mathrm{~min}$.

Data analysis 
Data are expressed as mean values $+/-$ SEM. of the indicated number of experiments.Statistical significance (here as $\mathrm{p}<0.05$ ) was evaluated with use of unpaired Student's $t$ test and showed as stars in the figures.

\section{Results}

3.1. PDE3B regulates insulin-induced glucose uptake, GLUT-4 translocation to the plasma membrane and lipogenesis

As shown in Fig 1, isoproterenol-induced lipolysis was potentiated both in the presence of the PDE3 inhibitor OPC3911 and the PDE4 inhibitor RO 20-1724. On the other hand, insulininduced decrease in lipolysis was blocked in the presence of OPC3911 but not RO 20-1724, indicating a key role for PDE3B but not PDE4 in the anti-lipolytic action of insulin, in agreement with previous results $[15,27,28]$. Very little is known regarding the role of PDE3B and PDE4 in other metabolic processes in adipocytes. As shown in Fig. 2A, insulininduced glucose uptake in adipocytes was inhibited by the PDE3 inhibitor OPC3911 in the presence of isoproterenol, a cAMP increasing $\beta$-adrenergic agonist (by 60\%). In the absence of isoproterenol, OPC3911-induced inhibition of insulin-induced glucose uptake appeared not to be significant. Similar results were obtained with milrinone, another PDE3 inhibitor (data not shown). A PDE4 inhibitor, RO 20-1724, did not affect insulin-induced glucose uptake.

We also tested the effects of OPC 3911 and RO 20-1724 on insulin-induced glucose uptake in the presence of pituitary adenylate cyclase-activating peptide (PACAP) and CL316243 ( $\beta_{3^{-}}$ adrenergic receptor agonist), which through interaction with G-protein linked receptors increase cAMP and lipolysis [29, 30]. The inhibitory effect of OPC3911 on insulin-induced glucose uptake was potentiated in the presence of both PACAP and CL316243 (data not 
shown) as was the case for isoproterenol. On the other hand, the inhibitory effect of OPC3911 was not potentiated by adenosine deaminase (ADA) which increases cAMP by degradation of adenosine (leading to removal of adenosine receptor mediated inhibition of adenylate cyclase).

Having shown that OPC3911 is a potent inhibitor of insulin-induced glucose uptake and lipogenesis, we next investigated whether the inhibitory effect was related to changes in GLUT-4 translocation from the cytosol to the plasma membrane. As shown in Fig. 3, stimulation of adipocytes with insulin resulted in an increased amount of GLUT-4 in the plasma membrane, as detected by western blot analysis. This increase was reduced in the presence of OPC3911, especially in combination with isoproterenol. In agreement with the functional studies, isoproterenol alone did not have any inhibitory effect on insulin-induced GLUT-4 translocation (data not shown). In both high density membranes (HDM) and low density membranes (LDM) the amount of GLUT-4 significantly decreased after stimulation by insulin. However, this decrease did not occur in the presence of OPC3911, especially in combination with isoproterenol. Thus, OPC3911-mediated inhibition of insulin-induced glucose uptake correlated with inhibition of translocation of GLUT-4 to the plasma membrane.

Insulin-induced glucose uptake is an important first step in several pathways leading to the storage of nutrients in the form of triglycerides (lipogenesis). As shown in Fig. 2B, insulininduced lipogenesis was inhibited in the presence of OPC3911 (by 45\%). The inhibitory effect of OPC3911 was further enhanced in the presence of isoproterenol, resulting in an approximately $70 \%$ inhibition of insulin-induced lipogenesis. On the other hand, isoproterenol alone had a small potentiating effect on insulin-induced lipogenesis as it was previously 
shown [29]. Milrinone, another PDE3 inhibitor, inhibited insulin-induced lipogenesis in the same manner as OPC3911 (data not shown). RO 20-1724 had little or no effect on insulininduced lipogenesis. Lipogenesis was also studied in adipocytes overexpressing PDE3B. Infection of 3T3-L1 adipocytes with AdVFlag-PDE3B led to a 35-fold overexpression of PDE3B (Fig. 4A, B), which resulted in almost 4-fold increase in lipogenesis as compared to control cells infected with AdV $\beta$-gal (Fig. 4C). These findings are in agreement with reduced lipogenesis in adipocytes treated with PDE3 inhibitors.

As shown in Fig. 5, OPC3911 and RO 20-1724 increased PKA activity both in the absence and presence of isoproterenol, whereas RO 20-1724 was slightly more efficient than OPC3911. Thus, different abilities of OPC3911 and RO 20-1724 to inhibit insulin-induced glucose uptake (in the presence of isoproterenol) and lipogenesis (both in the presence and absence of isoproterenol) do not correlate with their effects on total PKA activity. A minor role of PKA in mediating the effects of OPC3911 to inhibit insulin-induced glucose uptake (data not shown) and lipogenesis (Fig. 6) is further supported by the findings that H89, a PKA inhibitor, did not reverse these effects.

3.2. Epac is expressed in adipocytes and 8-pCPT-2'-O-Me-cAMP lowers insulin-induced glucose uptake, GLUT-4 translocation to the plasma membrane and lipogenesis

PKA independent cAMP signalling pathways have been described [31, 32] and cAMP has been shown to interact with GTP exchange factors, GEFs or Epacs (Exchange Proteins directly Activated by cAMP). Epac-mediated signaling was recently found to play a role in exocytosis [33], and in the activation of protein kinase B (PKB) [34], two events highly relevant for insulin-induced glucose uptake. As shown in Fig. 7, presenting western blots 
from total homogenate and subcellular fractions of adipocytes, Epac is expressed in adipocytes. In order to test the possibility that the inhibitory effect of OPC3911 on glucose transport and lipogenesis might be mediated by regulation of a PKA-independent pathway, an

Epac agonist, 8-pCPT-2'-O-Me-cAMP was used. As shown in Fig. 8, 8-pCPT-2'-O-MecAMP mimicked the ability of OPC3911 to reduce insulin-induced glucose uptake and lipogenesis. We then examined the influence of 8-pCPT-2'-O-Me-cAMP on GLUT-4 translocation and as shown in Fig. 9, the Epac agonist was able to impair translocation of GLUT-4 from an intracellular pool to the plasma membrane suggesting that the PKAindependent effects of OPC3911 could be mediated via cAMP/ Epac signalling.

Activation of PKB by insulin has been suggested to have an important role in glucose uptake and GLUT4 translocation [35] and Epac has recently been found to be involved in PKB activation [34]. However, as shown in Fig. 10, insulin-induced phosphorylation of PKB was not reduced in the presence of OPC3911, either without or with isoproterenol. It has also been demonstrated that insulin induces activation of the MAP kinase cascade, as well as cross-talk between $\beta$-adrenergic receptors and the MAP kinase in adipocytes [36]. However, addition of PD98059, an inhibitor of MEK (MAP kinase kinase), did not interfere with the ability of OPC3911 to inhibit insulin-induced glucose uptake or lipogenesis (data not shown).

\section{Discussion}

In this work we provide evidence that PDE3B, a key enzyme in the antilipolytic action of insulin [3], is also involved in the regulation of insulin-induced glucose uptake, translocation of GLUT-4 to the plasma membrane and lipogenesis in primary rat adipocytes. Treatment of adipocytes with selective PDE3 inhibitors OPC3911 and milrinone, but not RO 20-1724, a 
PDE4 inhibitor, resulted in lowering of insulin-induced glucose uptake and lipogenesis. These effects were potentiated by several different agonists known to stimulate receptor-mediated production of cAMP. This is in agreement with a previous study showing that the cAMP analogue, 8-bromo-cAMP, potentiated the ability of OPC3911 to inhibit insulin-induced glucose uptake [13]. On the other hand, ADA which increases cAMP by catalyzing degradation of adenosine [37] and therefore leads to removal of adenosine receptor mediated inhibition of adenylate cyclase, did not potentiate OPC3911 mediated lowering of insulininduced glucose uptake and lipogenesis, suggesting that PDE3B controls specific pools of cAMP. In agreement with some studies [2], but in contrast to others [38, 39], we found no inhibition of insulin-induced glucose uptake by the addition of isoproterenol alone. Rather, with regard to insulin-induced lipogenesis, we found a slight potentiation by isoproterenol, in agreement with previous results [29]. Differential effects of various cAMP-modulating agents, and especially the finding that OPC3911 but not RO 20-1724 had effects on insulininduced glucose uptake and lipogenesis, support the hypothesis of cAMP compartmentalization. Different pools of cAMP could regulate different downstream effects in both, PKA-dependent and independent manners. As for PKA-dependent processes, PKA anchoring proteins (AKAPs) [40] have been suggested to recruit PKAs as well as other proteins (e g. PDE4) [41] to different intracellular locations, resulting in compartmentalization of PKA signaling events. Our results using the Epac agonist, 8-pCPT-2'-O-Me-cAMP, which mediates PKA-independent cAMP signalling [31,32] and H89, a PKA inhibitor, suggest that the inhibitory effects of OPC3911 on insulin-induced glucose uptake and lipogenesis could occur by regulation of cAMP/ Epac signaling events. It should be noticed that inhibition of either PDE3 or PDE4 results in potentiation of isoproterenol-induced cAMP increase [42] and activation of PKA in adipocytes. Differential effects of PDE3/PDE4 inhibitors have also been demonstrated for insulin-induced inhibition of lipolysis; inhibition of PDE3, but not PDE4, 
blocks the antilipolytic effect of insulin [this study, 15, 27, 43]. Most likely PDE3B which is a membrane associated enzyme [3] regulates a cAMP pool different from a pool regulated by PDE4, an enzyme found mainly in the cytosolic fraction of adipocytes [28]. In a number of other cell types [44-46] and in several PDE3 and PDE4 knock out mice models [47-49] it has been demonstrated that different PDE family members have unique and non-overlapping functions presumably due to the regulation of different pools of cAMP. Although new methods are being developed in different laboratories for measurements of cAMP in real time and space in living cells, it is still unclear how cAMP, in response to different stimuli, triggers different cellular responses in one cell.

A correlation between cAMP-mediated inhibition of insulin-induced glucose uptake and inhibition of translocation of GLUT-4 to the plasma membrane has been shown in some studies [8] but not in others [6]. Isoproterenol-induced inhibition of insulin-induced glucose uptake in the presence of ADA was suggested to be caused by trapping of GLUT-4 in occluded vesicles associated with the plasma membrane during exocytosis, rather than by reduction of total plasma membrane GLUT-4 content [6]. Activity of the plasma membrane associated GLUT-4 transporter could explain some of the discrepancy between insulininduced glucose uptake and the amount of GLUT-4 in the plasma membrane. GLUT-4 has been shown to be phosphorylated $[7,50]$, and its phosphorylation was associated with the transport activity [7]. Our findings show a clear correlation between total plasma membrane, HDM, and LDM GLUT-4 content and inhibition of insulin-induced glucose uptake caused by OPC3911.

Mechanisms whereby inhibition of PDE3B induces inhibition of insulin-induced GLUT-4 translocation to the plasma membrane and inhibition of insulin-induced glucose uptake are not known. It is possible that PDE3B regulates a cAMP pool activating Epac-induced signalling events. Furthermore, signaling triggered by PDE3B involve targets downstream 
from PKB or on pathways parallel to the PKB signaling network. It might be possible that a PDE3B-controlled cAMP pool is involved in the regulation of proteins important for the transport or docking/ fusion of GLUT-4 exocytotic vesicles or in the regulation of atypical PKCs, kinases believed to play a role in insulin-induced glucose uptake [51].

Whether or not the ability of OPC3911 to inhibit insulin-induced lipogenesis can be explained solely by its effects on glucose uptake remains to be established. Most likely, other events downstream of glucose uptake are influenced by PDE3B inhibition since, in the conditions where OPC 3911 did not lower insulin-induced glucose uptake (Fig. 2A, without ISO), it significantly lowered insulin-induced lipogenesis (Fig 2B, without ISO).

In conclusion, PDE3B controls a cAMP pool, which through Epac-mediated signalling events, negatively regulates insulin-induced glucose uptake, GLUT-4 translocation to the plasma membrane, and lipogenesis. Our results suggest that Epacs or signalling components downstream of Epacs are interesting targets for the development of drugs for the treatment of insulin resistance.

\section{Acknowledgements}

This work was supported by the Swedish Research Council Project 3362 to E.D; Swedish

Diabetes Association; A. Påhlsson and Dr. P. Håkansson's foundations; Novo Nordisk, Denmark; The Swedish Society of Medicine. 


\section{Figures}

Fig. 1. Effects of PDE3 and PDE4 inhibitors on lipolysis and insulin-induced inhibition of lipolysis. Adipocytes were treated with $10 \mathrm{nM}$ isoproterenol (ISO) alone or in combination with either $10 \mu \mathrm{M}$ OPC3911 or $10 \mu \mathrm{M}$ RO 20-1724, in the absence or presence of 0.1 and 1 $\mathrm{nM}$ insulin (ins). Glycerol release was measured after $30 \mathrm{~min}$. Data are expressed as means +/- SEM., $\mathrm{n}=4$; *significantly different from corresponding isoproterenol-stimulated adipocytes (black bar in each panel).

Fig. 2. Inhibition of PDE3 but not PDE4 inhibits insulin-induced glucose uptake and lipogenesis. Adipocytes were treated with $1 \mathrm{nM}$ insulin (ins) alone or in combination with 10 $\mu \mathrm{M}$ OPC3911, $10 \mu \mathrm{M}$ RO 20-1724, or both, in the presence or absence of $30 \mathrm{nM}$ isoproterenol (ISO) for $10 \mathrm{~min}$, as indicated. $2-\left[1-{ }^{3} \mathrm{H}\right]$-deoxyglucose uptake (A) and lipogenesis (B) were measured and expressed as fold increase in comparison to control cells without or with ISO, respectively [in the ISO groups the control values are, in absolute terms, $8 \%$ (A) and $10 \%$ (B) lower as compared to the control values in the group without ISO; in a control experiment neither OPC3911 nor RO 20-1724 significantly influenced control values]. Data are expressed as means +/- SEM., $n=5$ (A), $n=15(B)$; *significantly different from corresponding insulin-stimulated adipocytes (black bar in each panel).

Fig. 3. Inhibition of PDE3B inhibits insulin-induced translocation of GLUT-4 to the plasma membrane. Adipocytes were stimulated with $1 \mathrm{nM}$ insulin (ins) with or without $10 \mu \mathrm{M}$ OPC3911 and $30 \mathrm{nM}$ isoproterenol (ISO) for 10 minutes. Representative GLUT4 immunoblots of the plasma membrane (PM), high density membrane (HDM), and low density membrane (LDM) fractions are shown. GLUT-4 bands from 3 experiments were quantified, 
and the intensity of each band was related to the intensity of the band in the control lane (for each experiment). Data are expressed as means $+/-$ SEM, $n=3$; *significantly different from corresponding insulin-stimulated adipocytes.

Fig. 4. Overexpression of PDE3B results in increased lipogenesis. Adenoviral stocks at $1 \times 10^{10} \mathrm{pfu} / \mathrm{ml}$ were used to infect adipocytes $(150 \mu \mathrm{l} / 2.5 \mathrm{ml}$ of $12 \%$ cells $)$ with Ad $\beta$-gal and AdFlag-PDE3B, respectively. Crude membrane fractions from control adipocytes and adipocytes overexpressing PDE3B were isolated and subjected to western blot analysis $(10 \mu \mathrm{g}$ of total protein) or PDE3 activity measurements. Shown is a representative western blot out of 5 independent experiments (A), PDE3B activity in membrane fractions expressed as fold increase in comparison to $\beta$-gal cells (B) and lipogenesis, also expressed as fold increase in comparison to $\beta$-gal cells (C). Data are presented as means $+/$-SEM.

Fig. 5. Inhibition of PDE3 or PDE4 induces activation of PKA. Adipocytes were pre-treated for 10 min with or without OPC3911 or RO 20-1724, and then stimulated with $30 \mathrm{nM}$ isoproterenol (ISO) or/ and $1 \mathrm{nM}$ insulin (ins) for $1 \mathrm{~min}$. PKA-activity was measured and expressed as fold increase in comparison to control cells without ISO. Data are expressed as means +/- SEM., n=3; *significantly different from untreated (control) adipocytes.

Fig. 6. Effects of H89 on insulin-induced lipogenesis. Adipocytes were pre-treated for $30 \mathrm{~min}$ with or without $10 \mu \mathrm{M} \mathrm{H89}$, and incubated with $1 \mathrm{nM}$ insulin (ins) alone or in combination with $10 \mu \mathrm{M}$ OPC3911 in the absence or presence of $30 \mathrm{nM}$ isoproterenol (ISO) for $10 \mathrm{~min}$. Lipogenesis was measured and expressed as \% of lipogenesis induced by insulin without or with ISO, respectively. Data are presented as means +/-SEM., $n=4$; *significantly different from insulin-stimulated adipocytes in the isoproterenol panel. 
Fig. 7. Expression of Epac in adipocytes. SDS-PAGE and western blot analysis were performed on total homogenate and subcellular fractions of adipocytes. Representative western blots show the content of Epac in total homogenate $(\mathrm{H} ; 60 \mu \mathrm{g}$ protein/well), plasma membrane (PM; $20 \mu \mathrm{g}$ protein/well), high density membrane (HD; $10 \mu \mathrm{g}$ protein/well), low density membrane (LD; $30 \mu \mathrm{g}$ protein/well) and cytosol (C; $40 \mu \mathrm{g}$ protein/well).

Fig. 8. 8-pCPT-2'-O-Me-cAMP inhibits insulin-induced glucose uptake and lipogenesis. Adipocytes were pre-treated for $30 \mathrm{~min}$ with or without $10 \mu \mathrm{M}$ 8-pCPT-2'-O-Me-cAMP, and incubated with $1 \mathrm{nM}$ insulin (ins) alone or in combination with $10 \mu \mathrm{M}$ OPC 3911, in the absence or presence of $30 \mathrm{nM}$ isoproterenol (ISO) for $10 \mathrm{~min} .2-\left[1-{ }^{3} \mathrm{H}\right]$-deoxyglucose uptake (A) and lipogenesis (B) were measured and expressed as \% of glucose uptake and lipogenesis induced by insulin without or with ISO, respectively. Data are presented as means +/- SEM., $\mathrm{n}=4$; *significantly different from corresponding insulin-stimulated adipocytes.

Fig. 9. 8-pCPT-2'-O-Me-cAMP inhibits insulin-induced translocation of GLUT-4 to the plasma membrane. Adipocytes were pre-treated for $30 \mathrm{~min}$ with or without $10 \mu \mathrm{M} 8$-pCPT2'-O-Me-cAMP, and incubated with $1 \mathrm{nM}$ insulin (ins) for $10 \mathrm{~min}$. Representative GLUT4 immunoblots of the plasma membrane (PM), high density membrane (HDM), and low density membrane (LDM) fractions are shown. GLUT-4 bands from 2 experiments were quantified, and the intensity of each band was related to the intensity of the band in the control lane (for each experiment). Data are expressed as means +/- STDEV.

Fig. 10. Effects of OPC3911 on insulin-induced phosphorylation of PKB. Adipocytes were incubated for $10 \mathrm{~min}$ with $1 \mathrm{nM}$ insulin (ins) alone or in combination with $10 \mu \mathrm{M}$ OPC3911 
or $10 \mu \mathrm{M}$ RO $20-1724$, in the absence or presence of $30 \mathrm{nM}$ isoproterenol (ISO). Cells were homogenized and centrifuged at $19000 \mathrm{~g}$ for $45 \mathrm{~min}$. Supernatants were subjected to immunoblot analysis using an antibody recognizing PKB phosphorylated on serine 473. Bands from 3 experiments were quantified using Fuji LAS 1000 Plus system. Results are expressed as means $+/$ - SEM.

\section{References}

[1] S.H. Soderling, J.A. Beavo, Curr Opin Cell Biol. 12 (2000), 174-179.

[2] S.H. Francis, I.V. Turko, J.D. Corbin, Prog Nucleic Acid Res Mol Biol 65 (2001), 1-52.

[3] Y. Shakur, L.S. Holst, T.R. Landstrom, M. Movsesian, E. Degerman, V. Manganiello, Prog Nucleic Acid Res Mol Biol. 66 (2001), 241-277.

[4] C. Holm, D. Langin, V. Manganiello, P. Belfrage, E. Degerman, Methods of Enzymology, 1997, Chapter 2, pp. 45-67.

[5] S. Rea, D.E. James, Diabetes 46 (1997), 667-677.

[6] H.G. Joost, R. Goke, H.J. Steinfelder, Biochem Pharmacol. 34 (1985), 649-653.

[7] M. Omatsu-Kanbe, H. Kitasato, FEBS Lett. 314 (1992), 246-250.

[8] A.D. Lee, P.A. Hansen, J. Schluter, E.A. Gulve, J. Gao, J.O. Holloszy, Am J Physiol. 273 (1997), 1082-1087.

[9] S.L. Macaulay, A.S. Kelada, J.Proietto, Mol Cell Biochem. 141 (1994), 27-33.

[10] C.M. Ferrara, S.W. Cushman, Biochem J. 343 (1999), 571-577.

[11] H. Nishimura, J. Saltis, A.D. Habberfield, N.B. Garty, A.S. Greenberg, S.W. Cushman, C. Londos, I.A. Simpson, Proc Natl Acad Sci U S A. 88 (1991), 11500-11504.

[12] I.A. Simpson, S.W. Cushman, J.J. Egan., A.D Habberfiel., C. Londos, H.Nishimura, J. Saltis, Biochem Soc Trans. 18 (1990), 1123-1125.

[13] J.W. Eriksson, C.Wesslau, U. Smith, Biochim Biophys Acta 1189 (1994), 163-167. 
[14] S. Shirakura, Y.Tokumitsu, Comp Biochem Physiol A. 96 (1990), 503-509.

[15] H. Eriksson, M.Ridderstrale, E.Degerman, D. Ekholm, C.J. Smith, V.C. Manganiello, P. Belfrage, H. Tornqvist, Biochim Biophys Acta 1266 (1995), 101-107.

[16] K. Imahashi, J. Yoshioka, T. Yamakita, S. Yamano, H. Kusuoka, T. Nishimura, Clin Exp Pharmacol Physiol. 28 (2001), 290-291.

[17] M. Ishikawa, R. Hosoi, K. Kobayashi, T. Nishimura, O. Inoue, Eur J Nucl Med Mol Imaging. 29 (2002), 1212-1215.

[18] M. Rodbell, J Biol Chem. 239 (1964), 375-380.

[19] R.C. Honnor, G.S. Dhillon, C.J. Londos, Biochem Soc Trans. 18 (1990), 1123-1125.

[20] T. Ramlal, V. Sarabia, P.J. Bilan, A. Klip, Biochem Biophys Res Commun. 157 (1998), $1329-1335$.

[21] A.J. Moody, M.A. Stan, M. Stan, J. Glieman, Horm Metab Res 6 (1974), 12-16.

[22] V. Dole, H.Neinertz,. J Biol Chem 235 (1960), 2595-2599.

[23] M.M. Bradford, Anal Biochem. 72 (1976), 248-254.

[24] M. Taira, S.C. Hockman, J.C. Calvo, P. Belfrage, V.C. Manganiello, J Biol Chem 268 (1993), 18573-18579.

[25] L. Harndahl, X.J. Jing, R. Ivarsson, E. Degerman, B. Ahren, V.C. Manganiello, E. Renstrom, L.S. Holst, J Biol Chem. 277 (2002), 37446-37455

[26] V.C. Manganiello, F. Murad, M. Vaughan, J Biol Chem. 246 (1971), 2195-2202

[27] M.L. Elks, V.C. Manganiello, Endocrinology 116 (1985), 2119-2121

[28] C. Schmitz-Peiffer, M.L. Reeves, R.M. Denton, Cell Signal. 4 (1992), 37-49

[29] L. Akesson, B. Ahren, V.C. Manganiello, L.S. Holst, G. Edgren, E. Degerman, Endocrinology. 144 (2003), 5293-5299.

[30] T. Umekawa, T. Yoshida, N. Sakane, M. Kondo, Endocr J. 44 (1997), 181-185. 
[31] J. de Rooij, F.J. Zwartkruis, M.H. Verheijen, R.H. Cool, S.M. Nijman, A. Wittinghofer, J.L. Bos, Nature. 396 (1998), 474-477.

[32] H. Kawasaki, G.M. Springett, N. Mochizuki, S. Toki, M. Nakaya, M. Matsuda, D.E. Housman, A.M.Graybiel, Science. 282(1998), 2275-2279.

[33] G.G. Holz, Diabetes 53 (2004), 5-13

[34] F.C. Mei, J. Qiao, O.M. Tsygankova, J.L. Meinkoth, LA. Quilliam, X. Cheng, J Biol Chem. 277 (2002), 11497-11504

[35] M.R. Calera, C. Martinez, H. Liu, A.K. Jack, M.J. Birnbaum, P.F, Pilch, J Biol Chem. 273 (1998), 7201-7204.

[36] K.J. Soeder, S.K. Snedden, W. Cao, G.J. Della Rocca, K.W. Daniel, LM. Luttrell, S. Collins, J Biol Chem. 274 (1999), 12017-12022

[37] R.C. Honnor, G.S. Dhillon, C. Londos, J Biol Chem. 260 (1985), 15122-15129

[38] C.J. Chang, J.T. Kao, T.L. Lee, C.W. Lai, J.T. Cheng, J Auton Nerv Syst. 61 (1996), 191-194.

[39] S.J. Vannucci, H. Nishimura, S. Satoh, S.W. Cushman, G.D. Holman, I.A. Simpson, Biochem J. 288 (1992), 325-330.

[40] J.J. Michel, J.D. Scott, Annu. Rev. Pharmacol. Toxicol. 42 (2002), 235-257

[41] K.L. Dodge, S. Khouangsathiene, M.S Kapiloff, R. Mouton, E.V. Hill, M.D. Houslay, L.K. Langeberg, J.D. Scott, EMBO J. 20 (2001), 1921-1930

[42] M.L. Elks, V.C. Manganiello, Endocrinology. 115 (1984), 1262-1268

[43] S. Enoksson, E. Degerman, E. Hagstrom-Toft, V. Large, P. Arner, Diabetologia. 41 (1998), 560-568.

[44] D.M. Juilfs, H.J. Fulle, A.Z. Zhao, M.D. Houslay, D.L. Garbers, J.A. Beavo, Proc Natl Acad Sci U S A. 94 (1997), 3388-3395.

[45] C.C. Chini, J.P. Grande, E.N. Chini, T.P. Dousa, J Biol Chem. 272 (1997), 9854-9859. 
[46] A. Tsafriri, S.Y. Chun, R. Zhang, A.J. Hsueh, M. Conti M, Dev Biol. 178 (1996), 393402.

[47] S.L. Jin, F.J. Richard, W.P. Kuo, A.J. D’Ercole, M. Conti, Proc. Natl. Acad. Sci. USA 96 (1999), 11998-12003.

[48] S. Masciarelli, K. Horner, C. Liu, S.H. Park, M. Hinckley, S. Hockman, T. Nedachi, C. Jin, M. Conti, V. Manganiello, J Clin Invest. 114 (2004), 196-205

[49] F. Rochais, G. Vandecasteele, F. Lefebvre, C. Lugnier, H. Lum, J. Mazet, D.M. Cooper, R. Fischmeister, J Biol Chem. 10 (2004), 52095-52105

[50] A. Schurmann, G. Mieskes, H.G. Joost, Biochem J. 285 (1992), 223-228.

[51] K. Kotani, W. Ogawa, M. Matsumoto, T. Kitamura, H. Sakaue, Y. Hino, K. Miyake, W. Sano, K. Akimoto, S. Ohno, M. Kasuga, Mol. Cell. Biol. 18 (1998), 6971-6982

Abbreviations used:

PDE, phosphodiesterase

PKA, protein kinase A

Epacs, Exchange Proteins directly Activated by cAMP

PKB, protein kinase $\mathrm{B}$

ADA, adenosine deaminase

PACAP, pituitary adenylate cyclase-activating peptide

HDM, high density membranes

LDM, low density membranes 


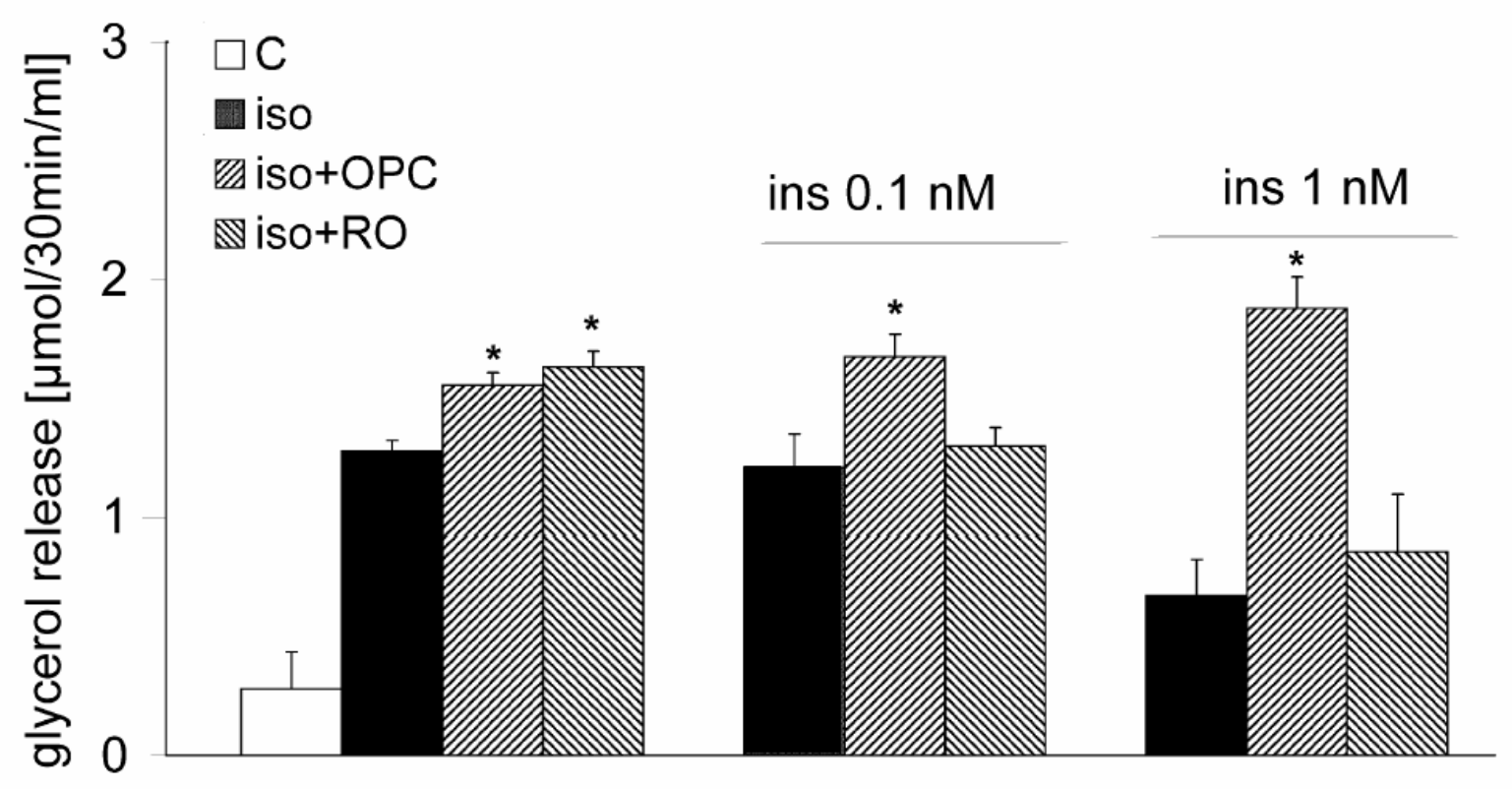

Fig. 1. 
A $\square$

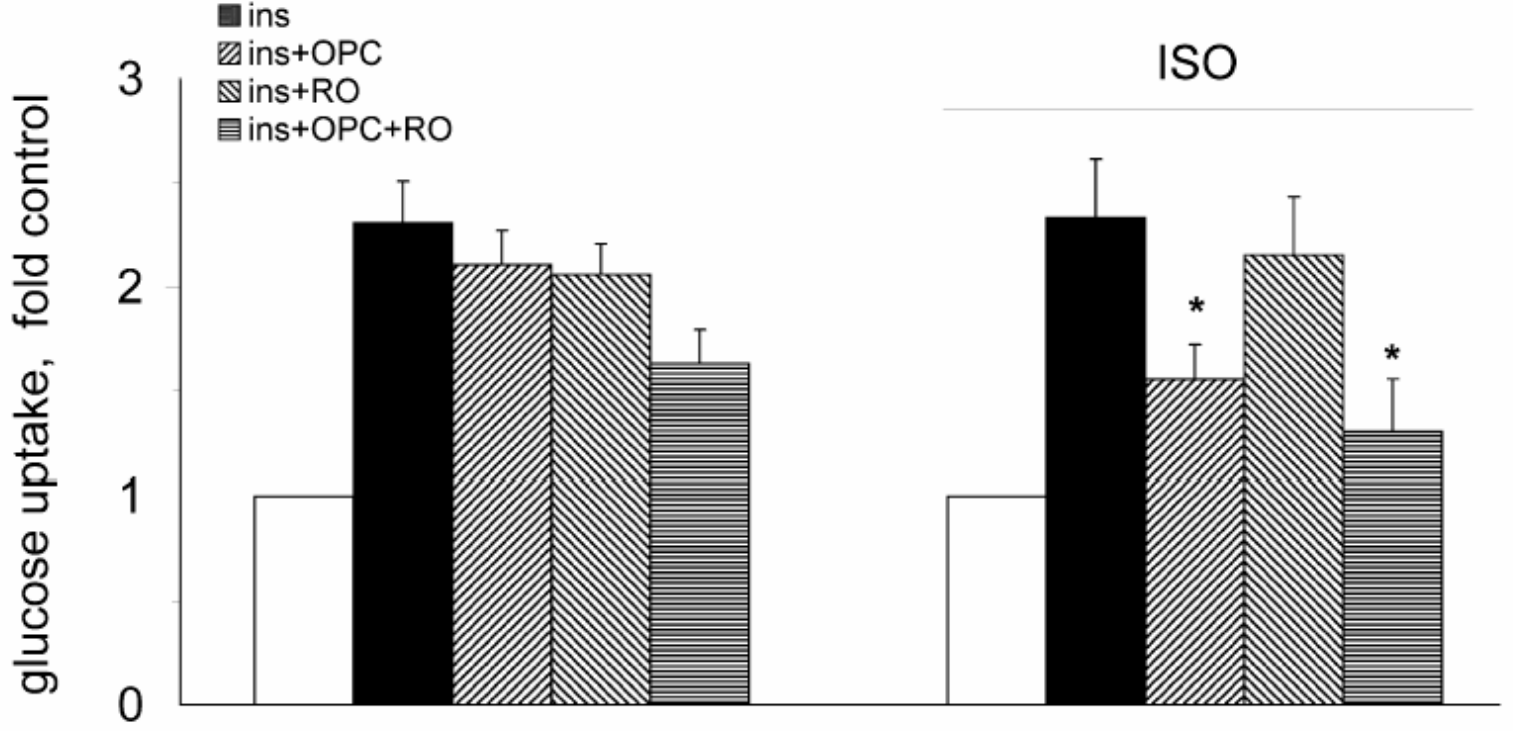

B

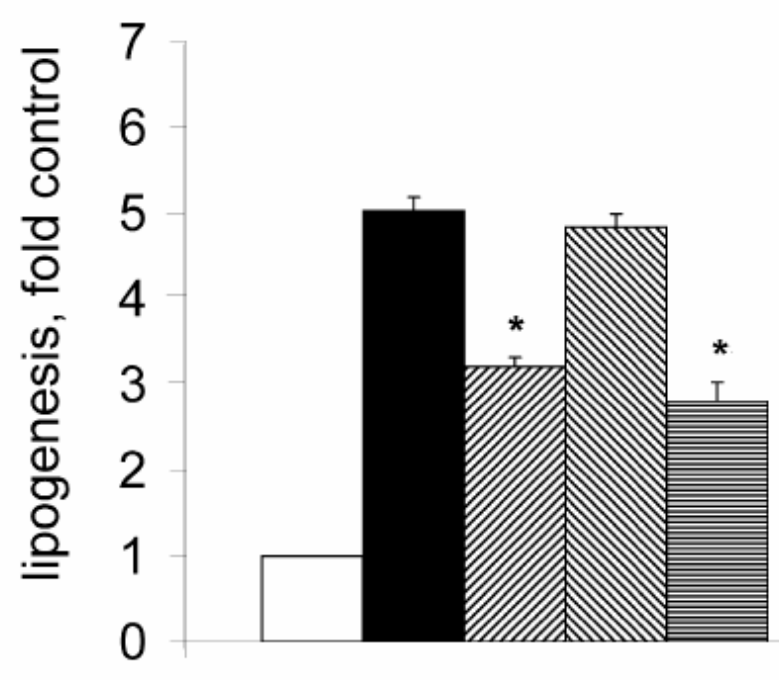

ISO

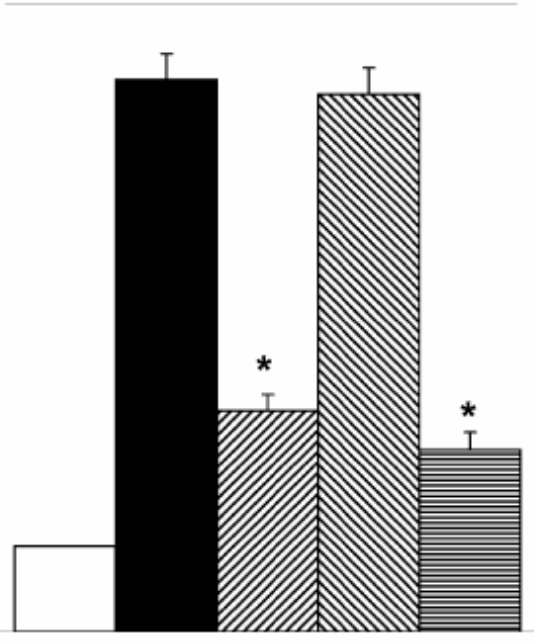

Fig. 2. 


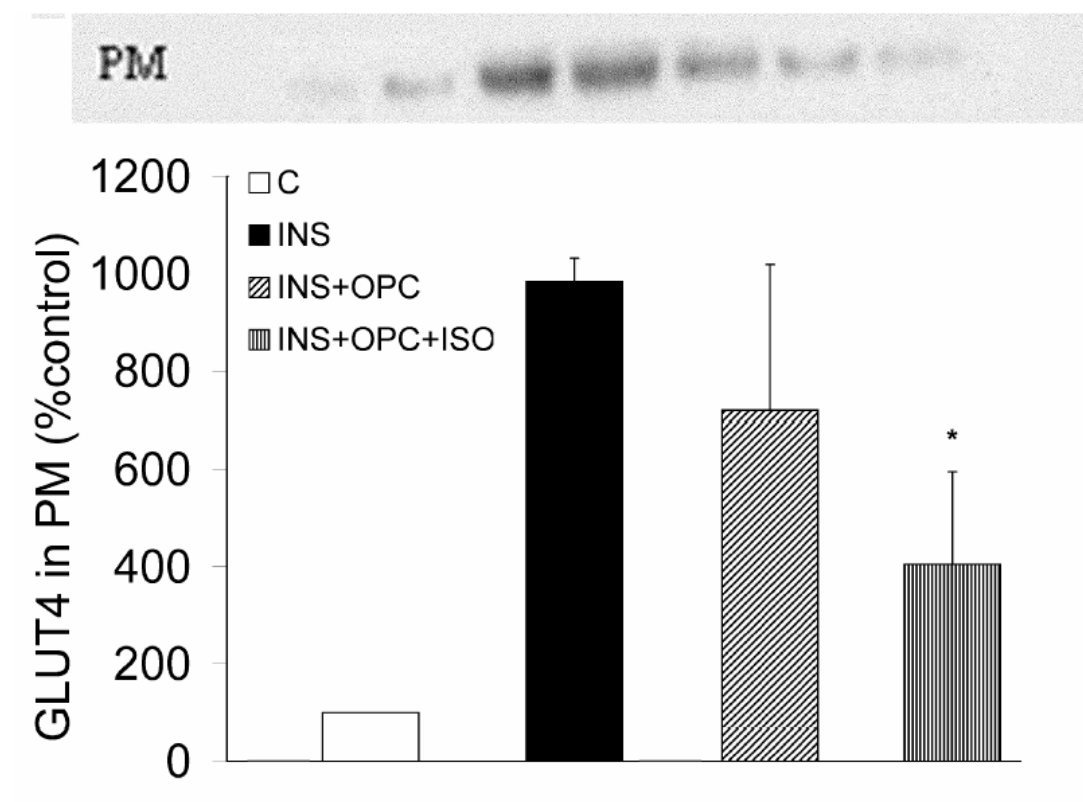

\section{HDM}

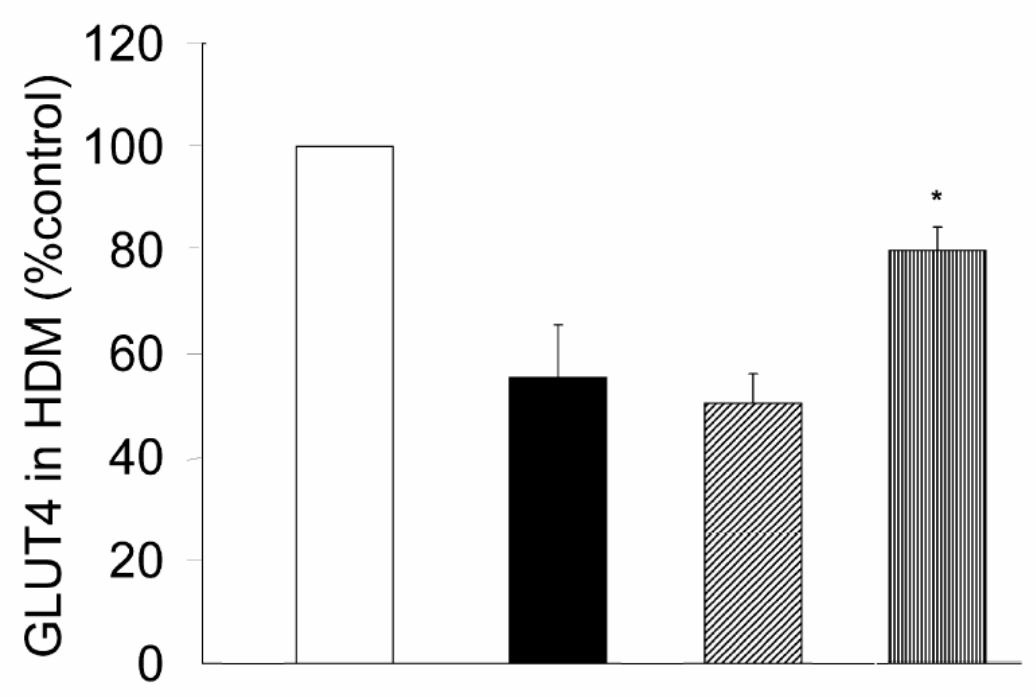

\section{LDM}

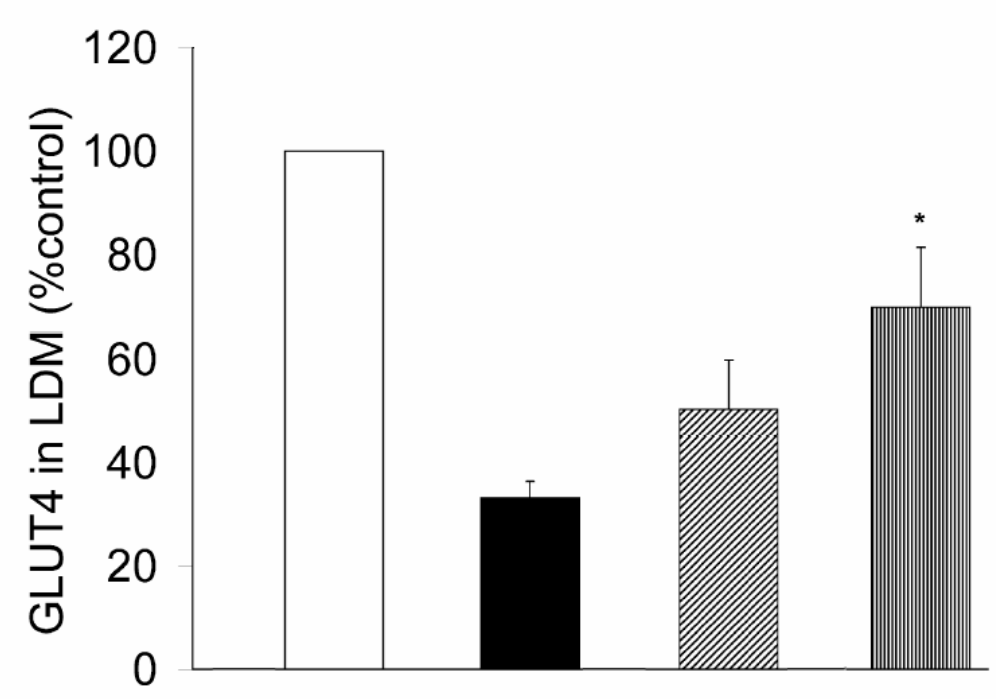

Fig.3. 


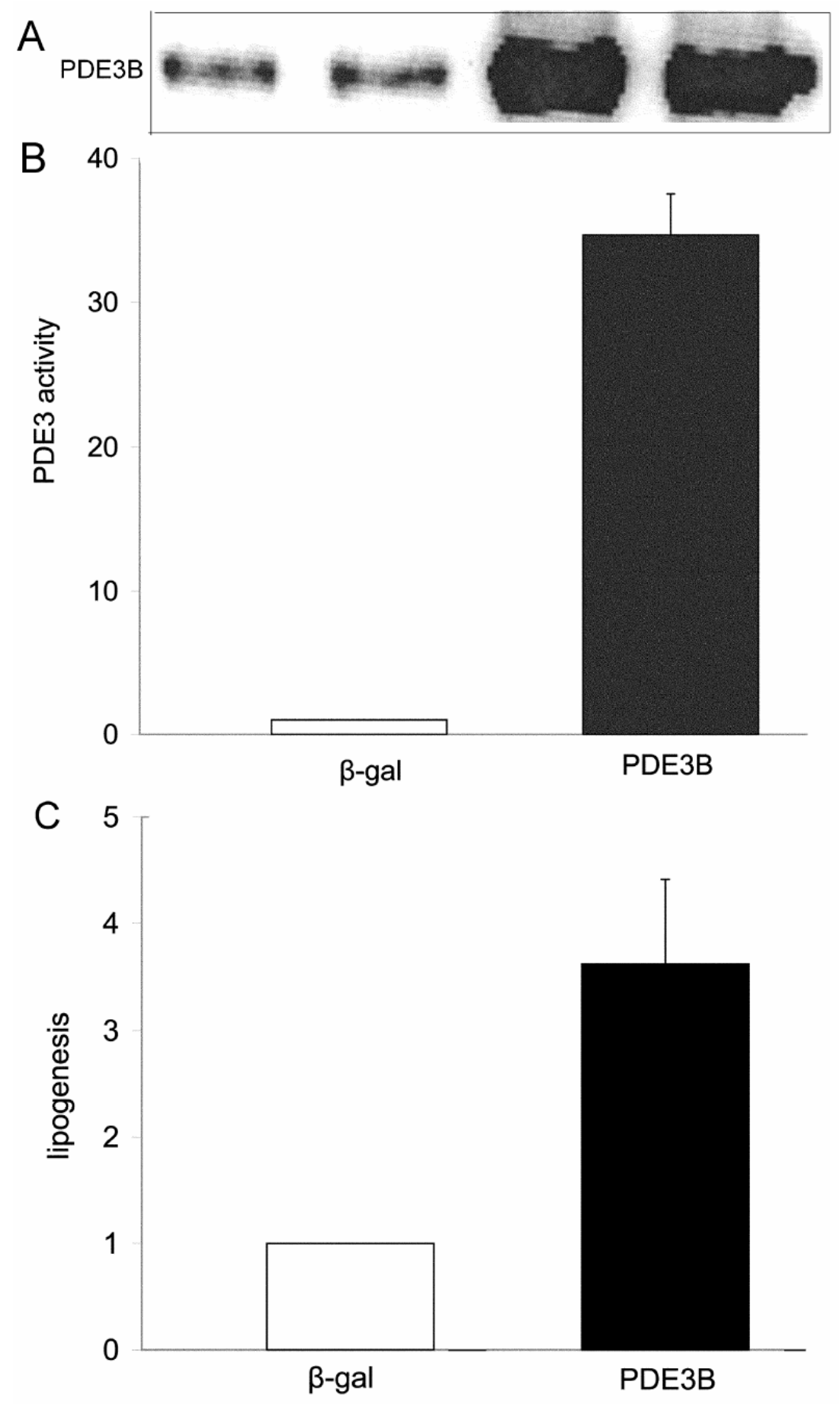

Fig.4. 


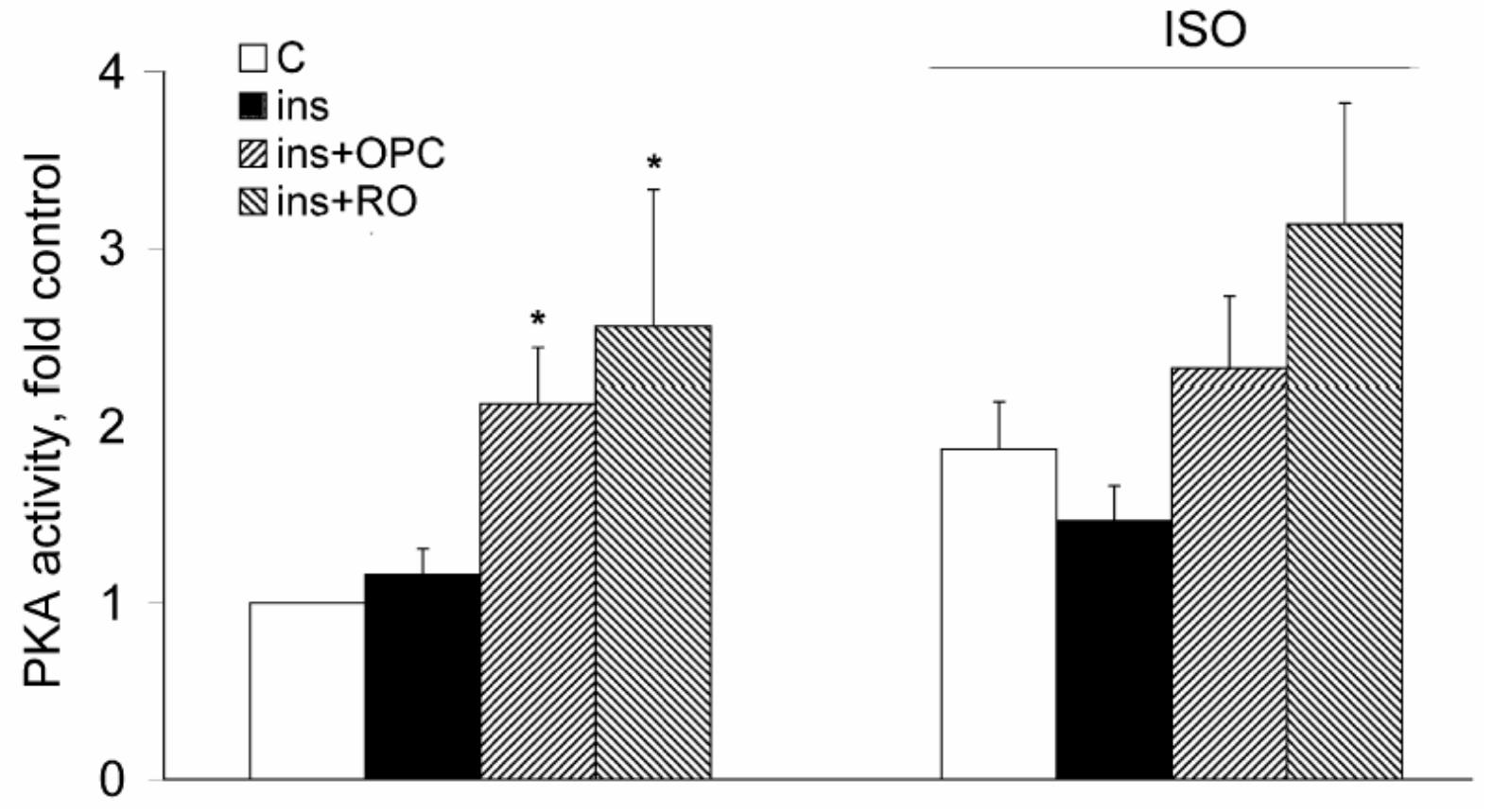

Fig.5. 


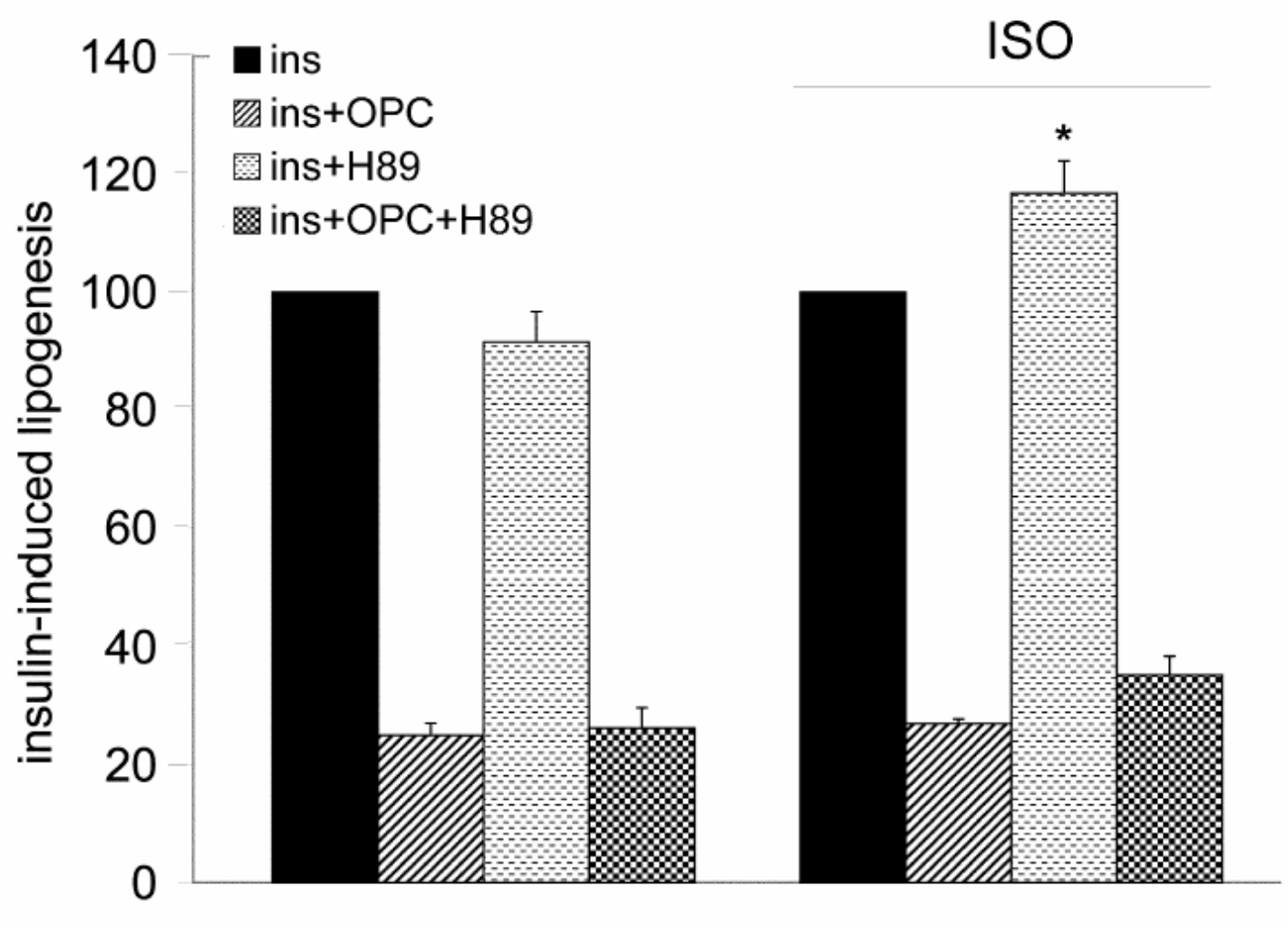

Fig.6. 


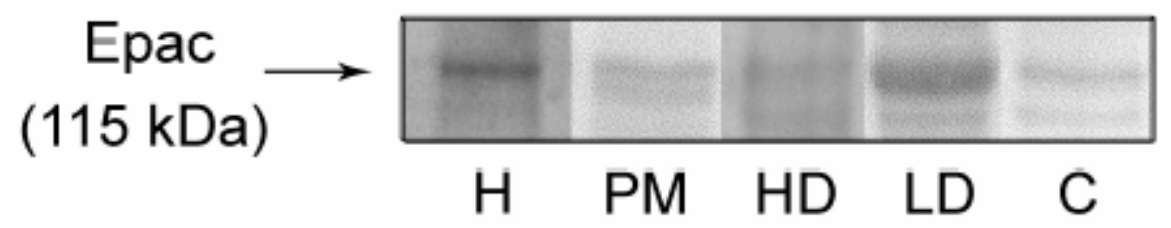

Fig.7. 
Dins

ins+OPC

A $\square$ ins+Epac agonist

2 100 ins+OPC+Epac agonist

ISO

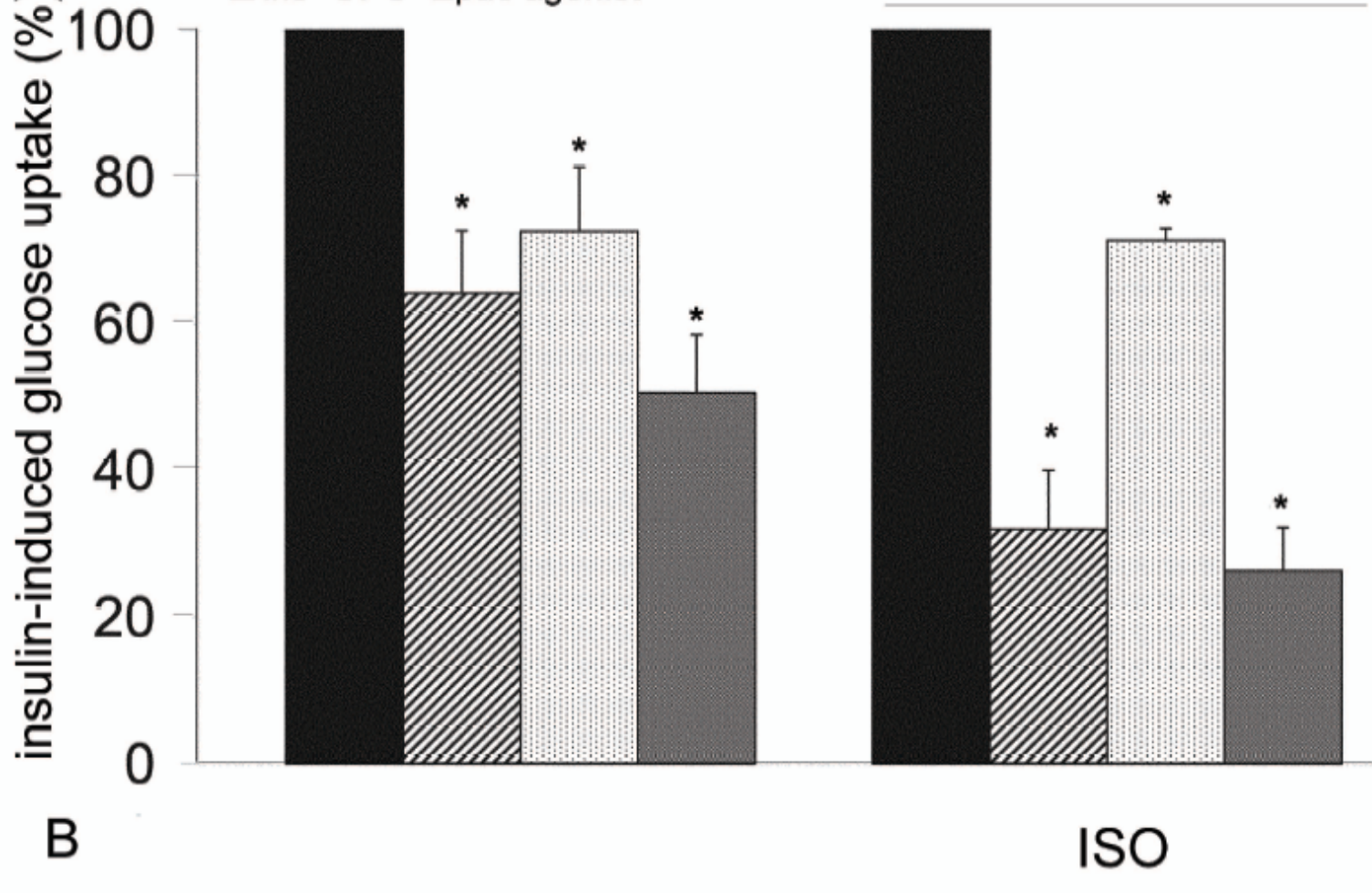

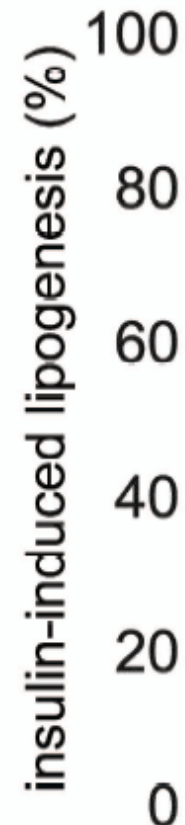
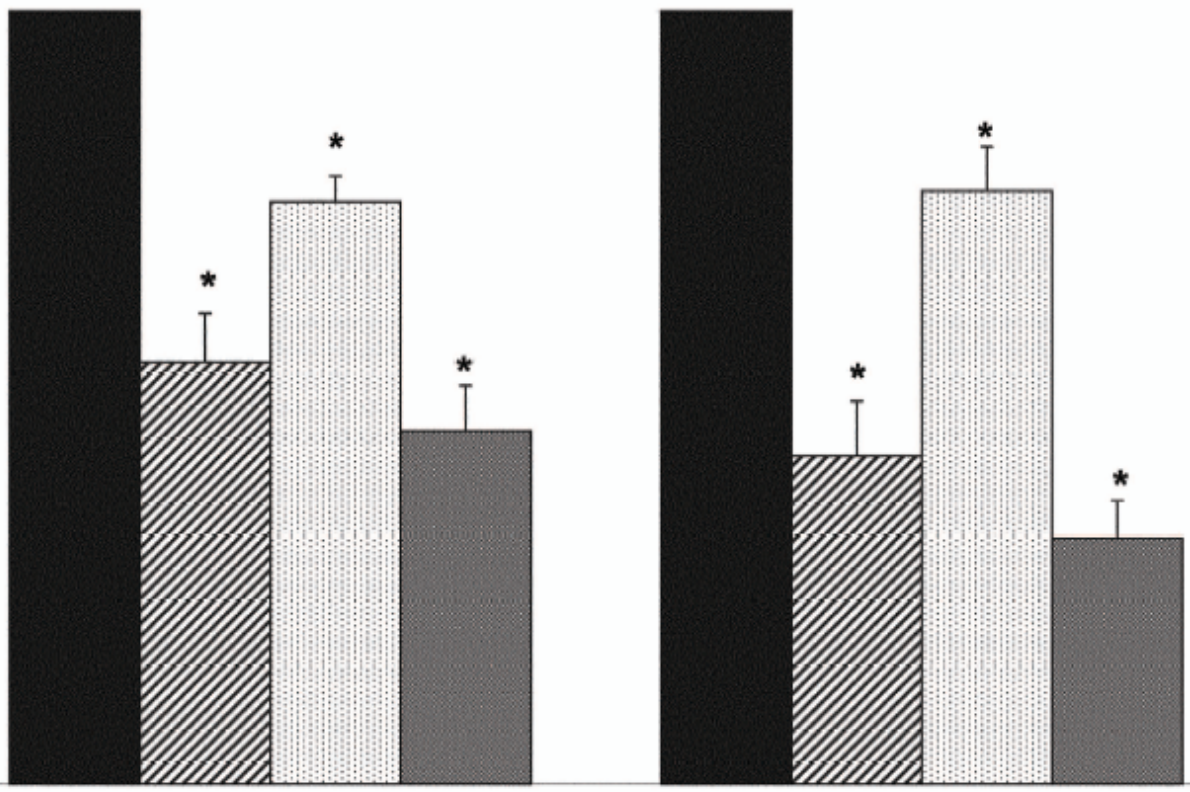

Fig.8. 

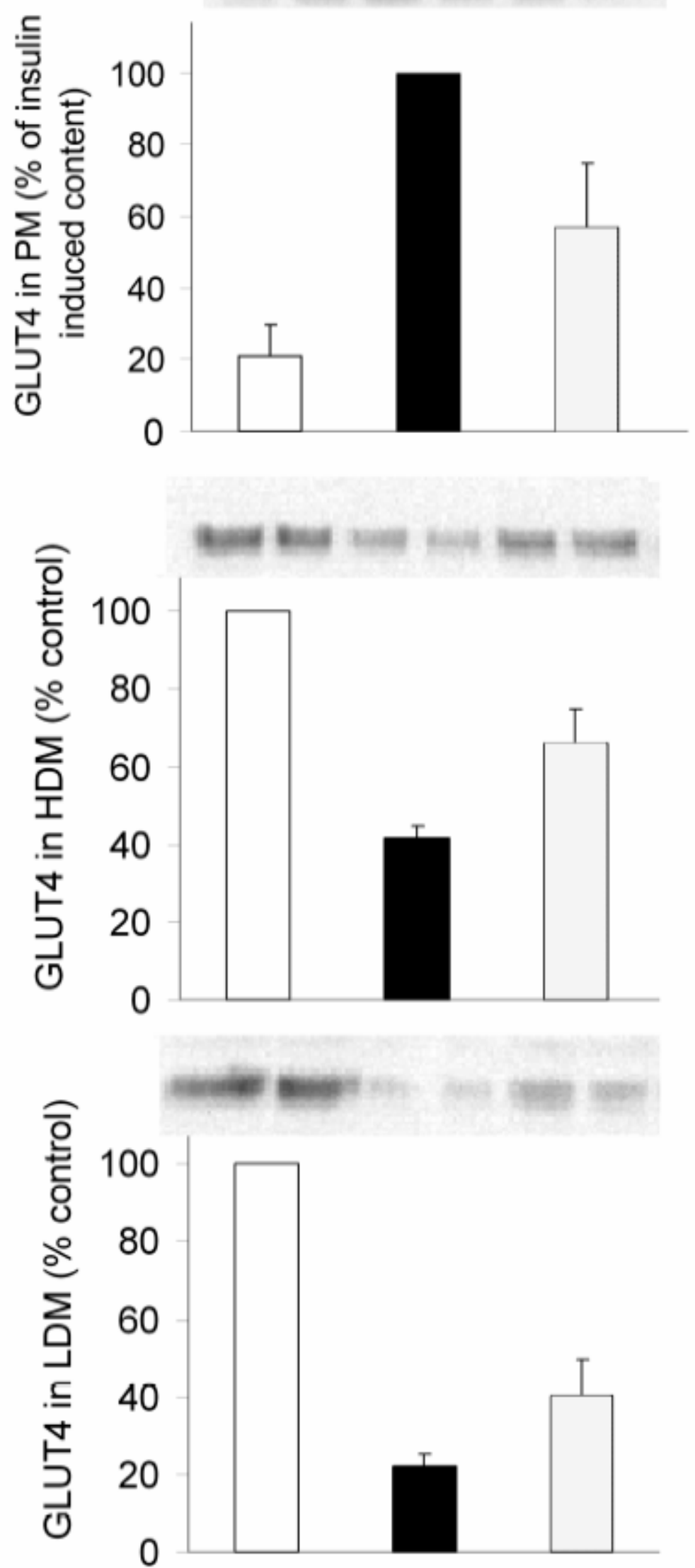

Fig.9. 


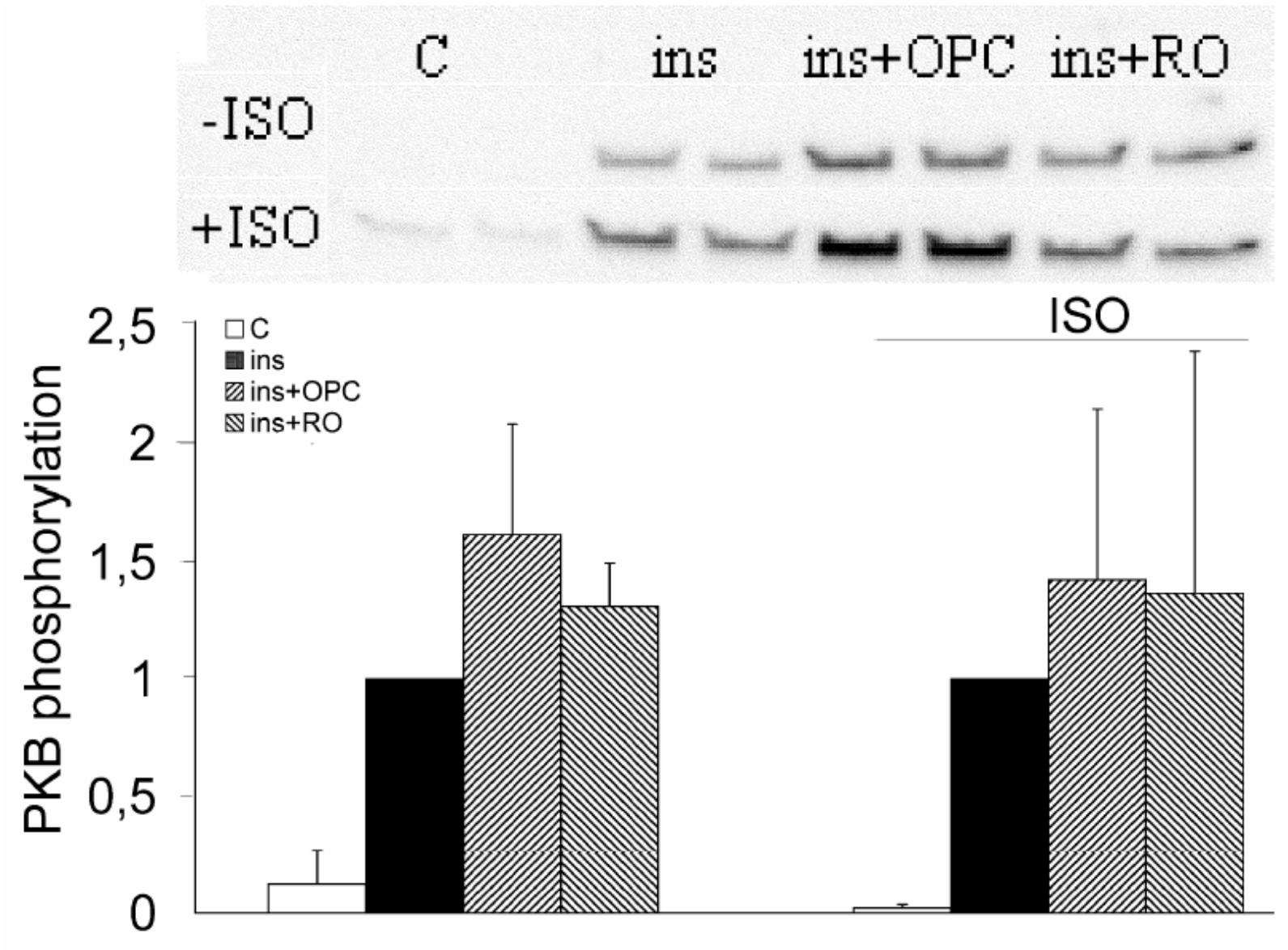

Fig. 10. 
